\title{
Russia's Energy and Defense Strategy in the Eastern Mediterranean
}

\author{
Andreas Stergiou \\ University of Thessaly, Volos, Greece
}

\begin{abstract}
The article seeks to illuminate Moscow's strategy in the Eastern Mediterranean in the energy and defense sector. For several years, an EU-NATO-Russian (NATO, North Antlantic Treaty Organisation) antagonism surrounding mainly energy and security has been raging in the Eastern Mediterranean, a region characterized by a remarkable, ongoing reconfiguration in the balance of power. Like the Soviet Union, post-Communist Russia followed, for geopolitical but also for purely economic reasons, a policy of "fishing in muddy waters", i.e. of a slow but steady penetration into Eastern Mediterranean countries. However, this penetration was achieved mainly through indirect tactics. Rather than making territorial demands and sending in their armed forces to annex, the Soviets, as their allies too, supported various political groups and governments with a view to weaken ties with the West and extend Soviet influence southward. They also sought to exploit social discontent emanating from EU-policies, as was the case with the EU bail-out policy towards Greece and Cyprus. In the wake of the Syrian Civil War, however, a new phase in Kremlin's policy in the region seems to have occurred. Indeed, the Syria War compelled Moscow, for the first time after the end of the WWII, to actively get involved in the domestic affairs of a country by using its military arsenal, though it was known that such a move would provoke Western counter-action. Kremlin's policy did precipitate some undesired fall-out for the Russians, such as deterioration in Tuskish-Russian relations and exacerbation of the existing Russia-EU/NATO antagonism. Russia seems to have multiple incentives to get involved in the war. Perhaps, the most important one is to strategically divert the West from Russia's primary interests in Europe, that is, Russian predominance in East-Central Europe. Furthermore, the Syrian campaign has been Moscow's attempt to retain the domestic prestige it won with the annexation of Crimea and to break out of the external siege that was laid by the West immediately afterwards by trying to fit into the new global order as a great power. In the second place, however, Moscow's activities in the region have also been addressing China's objectives to achieve as maximum as possible security of energy supply. This article tries for first time in the recent literature to illustrate Russia's strategy and policy towards Eastern Mediterranean from two different but intertwined aspects, defence, and energy. It is argued that for Moscow the region serves as an additional field with competition with the European Western countries and the USA.
\end{abstract}

Keywords: energy, geopolitics, security, EU, China, gas

Andreas Stergiou, assistant professor, Department of Economics, University of Thessaly, Volos, Greece.

Correspondence concerning this article should be addressed to Andreas Stergiou, University of Thessaly, Department of Economics, Korai 43, Volos 38333, Greece. 


\section{Introduction}

Interpreting Moscow's foreign policy in the Eastern Mediterranean is a very difficult task for several reasons. First of all, according to some observers, the Mediterranean does not constitute for Russia a more or less coherent region. On the contrary, Moscow has pursued over decades different policies towards the countries of the region on the ground of developing relations with at least four types of actors: North Africa and the Middle East, the southern EU members, countries involved in the challenges the Kremlin faces in the Black Sea region, and the United States, as Moscow's worldwide policies are captured by an idea of redrawing the negative consequences of a US-centred world order (Makarychev, 2009, pp. 169-172).

Apart of it, the region constitutes in geopolitical terms a very specific subsystem for whose analysis different, interpretative tools are required. At the crossroads of three continents, Europe, Asia, and Africa, the geopolitics of the Eastern Mediterranean does not involve only regional actors but also other actors placed along antagonistic, concentric circles: the United States, the Russian Federation, and the European Union. The Eastern Mediterranean has also been a meeting point of East and West, of the economic North and South, and of three major world religions: Christianity, Islam, and Judaism. The region is also at the apex of the two important geostrategic triangles formed in the north and north-east with the Black Sea and the Caspian Sea, and in the south and south-east with the Middle East and the Persian Gulf. One of the most sensitive areas is the Bosphorus, the cause of conflict is going back to at least the Trojan Wars, currently in Turkish territory, but subject to the international regime of the Montreux Convention. Therefore, it is a significant energy route and a potential energy hub too, as well as a route of illegal immigration, drug, and human trafficking. This explosive geopolitical complex is well manifested in the numerous conflicts that have historically occurred in the region, provoking fluid and changing patterns of alliances.

More precisely, due to the deterioration in relations between the USA's two most capable regional allies, Turkey and Israel, from 2008 onwards and the continuing fallout of the Arab Spring, the security and political order exists since the onset of the Cold War was broken down. This has been replaced by a widening Civil War in Syria and geopolitical rivalry among Turkey, Israel, Cyprus, and Greece and between Western countries and the emboldened revisionist powers of Russia and Iran. The EU-Cyprus-Greece-Israel energy cooperation was strengthened by Europe's interest in the diversification of supplies. Especially the crisis in Russia-Ukraine relationship and Moscow's decision in December 2014 to halt construction of the South Stream gas pipeline due to the unconstructive stance taken by the European Commission (Centre for Eastern Studies, 2014) played an important part in this respect.

The Syria War, however, added an imponderable variable to the power architecture of the greater Middle East, forcing the Kremlin to rapidly change its former strategy and to undertake, for the first time since WWII, military action was taken in the region. Given the sanctions imposed on Russia because of its intervention in Ukraine, Russia appears to look upon its involvement in Syria as a chance to lose the status of international pariah and to project power outside its region. This, however, as will be outlined in this study, has marked a groundbreaking moment in the history of Russia's presence in the Eastern Mediterranean since the 18th century, amounting to what has been called "A new Cold War".

Two elements compose new "Cold War" overall Russian strategy in this region, energy and military involvement. The energy factor is used to secure Russia's hegemonic position as traditional energy supplier of the West and as potential energy supplier of China that has become meanwhile a vital terrain for Russia's economic interests. 
Given China's large population, the large amount of energy is needed for its economic and social development and especially and its energy transition, which is unfolding at the very moment, gas discoveries in the region have gained unique significance for its energy security. Notably, China's energy demand is highly dependent on imports. It was estimated that the dependence on foreign oil will likely rise from $51.2 \%$ in 2008 to $70 \%$ in 2030 and from $5.8 \%$ to $50 \%$ for natural gas over the same period (Ren, Tan, Goodsite, Sovacool, \& Dong, 2015, p. 551). Thus, China's future energy security remains as an open question.

However, it should be mentioned that unlike oil, natural gas supply is particularly vulnerable to political influences because of the direct and long term nature of natural gas supply relations. Decisions on natural gas projects are especially likely to be affected by political considerations, because they can be quite risky. Investors, in general, have to wait a long time before receiving a return on their investments, and such investments involve immense sunk costs. Accordingly, regime stability and orientation are of paramount importance in decising where to develop natural gas projects (Shaffer, 2009, pp. 1-18). Russia's military involvement in the interstate affairs of the Eastern Mediterranean not only aims at undermining NATO's role in the security architecture in the region but also demonstrating Russia's military capabilities and potential as alternative security provider in a region suffocating traditionally by instability.

Taking into account recent Chinese investments in Greece which seem to be part of China's plan to create a network of roads, pipelines, railroads, and port facilities - sort of a modern Silk Road to boost East-West trade, the Eastern Mediterranean plays a central role due to its geographic position. The establishing of a nexus from the combined development of ports, shipbuilding, and maritime transport is facilitated by the fact that land and sea routes to Europe come together there. The largest and strategically most important Chinese infrastructure project in the region so far is the Cosco-operated container port at Piraeus in Greece (Shipping giant Cosco intends to implement total investments of 600 million euros at the port of Piraeus). In addition, China has interests in various other regional infrastructure projects. In June 2014, China's prime minister Li Keqiang attended the China-Greece Marine Cooperation Forum and visited the port of Piraeus where he gave a speech in which he explained China's overall maritime policy. The fact that he chose Greece as the location for this speech symbolizes this country's key role in China's maritime policy (Van der Puten, 2016).

\section{The Recent Reconfiguration in the Balance of Power in the Eastern Mediterranean and the Energy Factor}

Following the Russian-Ukrainian crisis in 2006, the increasing significance of the energy security issue and the necessity of diversifying the routes and sources of gas supplies to the European Union moved to the top of the list of EU priorities in its external relations, as was announced in the Second Strategic Energy Review in 2008. In 2010, about $80 \%$ of EU gas imports still derived from only three suppliers: the Russian Federation, Algeria, and Norway. This heavy dependence on such a few suppliers urged the European Commission to make the concept of diversification a cornerstone of its energy policy in the wider context of a common energy policy, enabling the EU to "speak with the same voice" on the need for sufficient diversity of exporters (Fondazione Eni Enrico Mattei Institute, 2013, p. 23). In spite of that, Russia is still the main supplier of oil, gas, and coal to the European Union, as well as one of its main providers of uranium. In 2013, Russia supplied 39\% of the gas, $33 \%$ of the crude oil, and $29 \%$ of the solid fuels imported by the EU (The Finnish Institute of International Affairs, 2015, p. 3). 
Therefore, there has been, notably, a genuine interest by Western European and US companies in gas supplies from the Caspian region (from Azerbaijan, Iran, Iraq, and Turkmenistan-especially since the president of the last country changed in late 2006/early 2007) - and hence EU-US politically support the so-called Southern Gas Corridor and Trans-Adriatic pipeline (TAP), the supply routes running from Azerbaijan via Turkey to Europe (Jarosiewicz, 2015, pp. 9-10).

The discovery of natural gas resources in the Eastern Mediterranean since the late 2010s has also predictably attracted EU/US's interest, given the enormous European demand for the relatively cleaner power of natural gas as well as attempts to create a competitive, interconnected, and well-functioning internal market and develop a coherent and collective external strategy. The latter would also allow EU countries to both diversify and secure their gas supply from abroad (Jacques Delors Institute, 2013).

Furthermore, this would coincide with Washington's long pursued aim of putting an end to Moscow's tactic of using its natural gas exports to exercise economic and political influence in Europe. (The Begin-Sadat Center for Strategic Studies, 2011, pp. 32-34). The Kremlin believes that the domestic energy industry should be organized in two legal regimes. Unlike the oil-companies that should be private, gas companies (Gazprom) should be state-run companies for two reasons: first, in order to control gas prices on which so many people depend (Gazprom controls about 90\% of the Russian market), and second, Gazprom's activities are fully intertwined with Russia's foreign policy. ${ }^{1}$

However, as it is widely known, due to a series of diplomatic confrontations between 2008 and 2012, the relationship between Israel and Turkey has entered a period of great tension, following 50 years of close and successful cooperation. After Turkish-Israeli's ties became strained, in a classic example of "the enemy of my enemy is my friend," Israel and Cyprus and, by extension, Greece, came together to form a defense-economic alliance which could, under certain conditions, be turned against vital Turkish interests in the region. The economic benefit expected from the substantial natural gas and oil resources discovered in the Exclusive Economic Zones of Israel and Cyprus has also contributed to the materialization of an unprecedented political, military, and energy relationship (Stergiou, 2015, pp. 417-428).

Nevertheless, the EU-Cyprus-Greece-Israel cooperation has been in conflict with Turkey's geopolitical aspirations in the region. Turkish economic and political elites would view a possible export route to European markets through the Mediterranean, connecting Israel, Cyprus, and Greece, as a threat to their own ambition to transform Turkey into the major non-Russian transit route for gas sales and a regional energy hub (Eksi, 2010, pp. 62-65). Ankara has been contesting the fact that the areas with gas reserves in the eastern basin of the Mediterranean, stretching from the Levant coast to southern Crete and maybe beyond, are situated in clearly divided national waters, thereby ignoring Republic Cyprus's rights and jurisdiction over the maritime areas of the island (Inan \& Gözen, 2009, pp. 153-211).

Furthermore, it repeatedly threatened Cyprus with military action, even while US-company Noble Energy was still carrying out exploratory drilling off the island's southern coast, thereby creating tensions in the region by dispatching Turkish military vessels. As a result, the recently forged Israel-Cyprus-Greece alliance has a well-shaped military character. Indeed, in spring 2012, Israel and the United States invited Greece to join them in joint military exercises through which Israel sought to replace strategic depth it had lost after the termination

\footnotetext{
${ }^{1}$ Alexander Sotnichenko, Former Russian diplomat in Israel and currently Associate Professor at the Saint Petersburg State University, School of International Relations, personal communication, Jerusalem, July 2013.
} 
of the defense cooperation with Turkey. ${ }^{2}$ At the same time, Washington has been trying to mediate Israel and Turkey to resolve the crisis in their bilateral relations, but also Turkey, Cyprus, and Greece in a bid to resume negotiations to settle the Cyprus conflict.

Within the framework of the geopolitical and geo-economic shift of power looming in the region, Turkey initially turned to Moscow, seeking to foster its energy cooperation with Russia-also in the field of nuclear power-in order to counterbalance these US-EU plans in the Eastern Mediterranean, fueling a new form of US-Russian rivalry in the region.

Following the disintegration of the Soviet Union, relations between Russia and the countries of the region have been marked by cooperation, but also by rivalries and competition. Russian-Turkish relations constitute a typical example in this respect. Despite numerous agreements in the fields of economy, technology, science, culture, health, and tourism, Russia never stopped regarding Turkey as a threat and competitor to its interests in Central Asia and Caucasus, where Russian and Turkish ambitions clashed actively and repeatedly for dominance. The traditional ties of the Turkey's Kemalist establishment with the USA and Turkey's aspirations of using its key geo-strategic to fill the geopolitical vacuum occurred in the region after the collapse of the USSR put obstacles in the improvement of Turkish-Russian bilateral relations. The territorial conflict between Azerbaijan and Armenia provided an additional bone of contention. As widely known, Armenia occupied Nagorno-Karabakh and seven surrounding Azeri districts in 1993. While Russia upheld Armenia's claim to the occupied territory, Turkey was the most ardent supporter of the Azeri positions in the international arena (Takin \& Williams, 2011, pp. 160-161).

However, the Iraq war in 2003 and the establishing of a de facto Kurdish state in Iraq as a result of the US-invasion substantially affected US-Turkish relations, precipitating as side-effect in an improvement in Russian-Turkish relationship. That bilateral progress was also favoured by the gradual diminishing of the tensions in Central Asia as well as Russia's emergence as a profitable market for Turkish entrepreneurs. Particularly, the energy parameter of those ties played a guard role (Yanik, 2007, pp. 349-367; Sener, 2006, pp. 337-364).

The clinching of various energy deals was designed to enforce Turkey's drive to become a regional hub for gas and oil transits as well as to help Moscow to diversify supply routes and potentially maintain its monopoly on natural gas shipments from Asia to Europe. Turkey, which has been highly dependent on Russian energy (especially gas) supplies, allowed Russia's Gazprom to use its sector of the Black Sea for the South Stream pipeline to pump Russian and Central Asian gas to Europe bypassing Ukraine and Russia and joined a consortium with the aim to build the Samsun-Ceyhan oil pipeline from the Black Sea to the Mediterranean. As it has been asserted by some experts (Takin \& Williams, 2011, p. 107; pp. 146-149), this has been coinciding with Gazprom's aims to control the entire value chain on the European Market. Therefore, it sought to dominate the construction and operation of prestige projects like Nord Stream and South Stream gas pipelines, just as Transneft, the other Russian energy giant, sought to exert influence over oil projects, like the Trans-Black Sea Burgas-Alexandroupolis pipelines.

\footnotetext{
${ }^{2}$ An important annual naval event in the Mediterranean is the codenamed Reliant Mermaid that was first held in 1998 and originally involved Turkey. However, from 2011 onwards, after Turkey withdrew, Greece was invited to take its place. With Athens on board, the exercise was renamed Noble Dina and the overall mission of the training was changed from search and rescue exercises to attack and defend scenarios that included repelling enemy assaults, anti-submarine warfare and aircraft operations as well as attacks on offshore natural gas and oil rigs.
} 
The reconfiguration of the power balance in the Eastern Mediterranean in recent years offered Russia the opportunity to proceed in a reestablishing of its energy and defense cooperation with almost every country in the region. The motives behind those actions are obvious. Moscow tried to undertake pre-emptive action against everything that can undermine its hegemonic position as energy-provider to the European Markets and to the countries of the Eastern Mediterranean.

In December 2011, Russia and Turkey signed an agreement on the South Stream natural gas pipeline, allowing Russia to build the South Stream gas pipeline through Turkey's exclusive economic zone. On the same day, Gazprom signed an annex to its gas contracts with the Turkish corporation BOTAS, which allows it to increase the supply of Russian gas, possibly leading to a significant reduction in its price (Stergiou, 2012).

In July 2012, President Vladimir Putin visited Israel to promote a Gazprom deal with the Israeli government (formally as the guest of honor to inaugurate a monument to the Red Army soldiers who defeated Hitler in World War Two) that would give it control of Tamar's gas and access to the Asian market for its liquefied natural gas. ${ }^{3}$ A few months later, however, Russia started negotiations with the Palestinian Authority on a possible development of the Gaza Marine Field (Vogler \& Thompson, 2015). The Israeli-Russian relationship is quite complicated. With the emergence of Putin, Israel seems to have found the closest thing to a friend as it has ever had in Moscow. In 2014, Putin was one of the few world leaders to support Israel's Operation Protective Edge against Hamas. After Russia annexed Crimea, Israel abstained from voting on a United Nations resolution condemning Russian actions - which in UN diplomatic vocabulary is actually equivalent to vote against it (J. Cohen, 2016). Notably, Russia is Israel's largest supplier of crude oil and a big recipient of agricultural imports from Israel. Russia's deployment of advanced surface-to-air S-400 missiles, though, has been of grave concern to Israel, as Tel-Aviv never stopped fearing the transfer of advanced weapons from Iran or Syria to archenemy Hezbollah. The more critical of Israel's treatment of Palestinians, particularly of its settlement policy in the West Bank the European Union became, the more common ground Tel Aviv found for cooperation with Moscow. For several years, Gazprom's main concern has been that Israel's entry into European gas markets would severely undermine the company's market power.

From 2013 onwards and especially under President Abdel-Fattah El-Sisi, Moscow also revived its strong relationship with Egypt as it became obvious in the array of cooperation agreements on trade and nuclear energy that have been signed. Moscow and Cairo are also deepened military cooperation, while Egyptian diplomacy appeared to have paved the way for the Saudi-Russian rapprochement. Egypt has also very quietly endorsed the Russian approach to resolving the Syrian conflict, as it supports preserving the Syrian state and its institutions, included President Bashar al-Assad regime (Siman, 2016).

In 2013-2014, Russia made moves towards more challenging alternatives. In May 2013, Russian companies were allowed to build and own a 20 billion US-dollar nuclear power plant on Turkey's southern Mediterranean coast. At the same time, Russian companies (Gazprom and Russian Railways) attempted to purchase Greece's main state-run gas and oil company (DEPA), one of the participants in the South Stream project and the main gas supplier to the Greek market, and Greek Hellenic Railways Organization (OSE) in order to control energy and transport infrastructure. However, it is a common secret in Greece that, before the Russian companies' intention materialized, EU institutions intervened and repealed the project. Relying on the

\footnotetext{
${ }^{3}$ Israel needs both Russian diplomatic support and Russian Now How for the exploitation of the resources, while Gasprom has been keen to be involved in the exploitation of the new energy reserves but the right parties are against. However, there are many ressentiments from the Soviet and Russian Support to the Arabs (Personal Communication with Alexander Sotnichenko).
} 
legal background of the EU Third Energy Package, which does not allow gas producers to possess their own gas transportation systems at the same time (although Azerbaijan's SOCAR bought out Greek gas transporter, DESFA), the EU Commission raised objections to the deal and Gazprom was compelled to withdraw interest for Greek gas firm.

In October 2013, Russia and the Libanon signed an energy cooperation Memorandum of Understanding for developing natural gas fields off the Lebanon's shore. Several Russian companies also bid for the Lebanese exploration tender, while the Russian state-owned Soyuzneftegaz Gas Company clinched an agreement with the Syrian Ministry of Energy in December 2013 in order to explore in its Offshore Block 2 (Günaydin, 2014). That very promising 25-year deal signed with the Damascus' regime appears to have been an additional driving force behind Moscow's gambit to further bolster Assad, as it is estimated that the existing energy finds in the Levant Basin extend into Syria's offshore territory (Cropsey \& Brown, 2014, p. 10).

Moreover, since the beginning of the Syrian crisis, Moscow has gradually augmented its naval presence in the region. Since 2011, Moscow has repeatedly dispatched fleets of five or six combat ships to the Mediterranean with frigates, cruisers, and aircraft carriers to conduct military drills. The Russian fleet's activities in an area that is very sensitive for NATO, obviously connected with the civil war in Syria, have no precedent since the Cold War in terms of size of forces involved, the measures employed, the territorial span, the number of exercises, or the scheduling and methodology of the drills. The intensity of the activities of the Russian Navy in the Mediterranean and the military means engaged are comparable, in due proportion, with Soviet fleets' moves during the Vietnam War (Centre for Eastern Studies, 2013).

In the same context, in August 2013, the Kremlin submitted an official request to rent the Andreas Papadopoulos airfield near Paphos, even though since 2012 Russian naval vessels had been using the Limassol port for refueling. Cyprus has been a key-component of Kremlin's policy in the region and an apple of discord within the Western powers over the decades, not only because of its strategic importance. Moscow has traditionally declared its commitment to safeguarding Cyprus's state sovereignty and neutrality in order to avoid the pro-NATO militarization of the island. Since the Republic Cyprus has not been a NATO member and hence is not constrained by any alliance-restrictions, has been developing from mid of 1990's onwards a close defence cooperation with Russia (Stergiou, 2011).

Official Cypriot-Russian relations date back to the 1960's, when the USSR established diplomatic relations with the newly independent Republic of Cyprus. In 1982, the two states signed an agreement on double-taxation avoidance. As a result, at the beginning of the 1990s, Cyprus was one of the few capitalist countries with an institutional framework for Russian capital outflows and inflows from Cyprus already in place.

From the early 1990's onwards, the island rapidly became one of the favored destinations for Russian capital (Central Bank of Cyprus, 2002). Some scholars believe that money laundering and tax evasion were the main driving forces behind capital movements (Pelto, Vahtra, \& Liuhto, 2003, pp. 11-16). Russians were among the most active non-resident portfolio investors to the Cyprus Stock Exchange with the overwhelming majority of the invested money deriving from Russian capital flight. Cyprus's accession into the European Union in 2004, albeit it induced a large volume of legislative changes to bring Cyprus into line with the EU, did not halt this tendency. Cypriot capital was also a major investor in Russian securities market. These investments are often considered to mean the return of Russian capital. To a large extent, these outbound investments act as safety nets for Russian companies to protect themselves from uncertainties in the domestic 
environment. However, the top position of Cyprus may also indicate that many foreign companies trading with Russia use Cypriot subsidiaries in order to take advantage of the favourable taxation in Cyprus (Fabry \& Zeghni, 2002, pp. 293-294; Liuhto \& Majuri, 2014, pp. 199-200).

In October 2010, the two countries signed a new agreement (Convention for the Avoidance of Double Taxation of Income and Property) to avoid double taxation, which further increased the flow of investment. The common characteristic of all the double tax treaties Cyprus signed is reducing or eliminating the normal withholding taxes imposed by the contracting states on dividends, interest, and royalty payment. Cyprus does not impose withholding tax on payments of dividend, interest, and royalties paid by international business companies. Therefore, the Cyprus international company is mostly used to receive dividend interest, royalties, and capital gains from the other treaty country so that the withholding tax is reduced. The interest and royalty payment in most cases are a deductible expense in a high tax jurisdiction, whereas the capital gain is exempted from tax (Pilides, 2002, p. 6).

Eventually, in February 2015, despite US's opposition, Cyprus agreed to allow some Russian naval ships to make stops at its ports with the aim of counter-fighting terrorism and piracy; in return, Russia agreed to provide debt relief to the Republic of Cyprus, restructuring the 2.5 billion euro bailout loan it had given Cyprus in 2011 (Razumovskaya, 2015).

In 2011, Cyprus had experienced significant difficulties due to the debt crisis in Greece, to which the island is closely economically linked. Despite the fact that Cyprus was unable to pay the debt on bonds worth around 1.2 billion dollars in early 2012 without external financial assistance, in August 2011, the European Commission announced that it would not allocate credits to Cyprus, similar to those issued previously in Greece. As Cypriot banks - the fundamental pillar of the island's economy-were heavily exposed to the debt of the Greek state and large sum of rescue money was required to shore them up, credit rating agencies dramatically downgraded Cypriot debt rating to junk status. Since Cyprus was then effectively excluded from international markets, the communist at that time, government in Nicosia, with strong ties to Russia since the time of Cold War, sought help from Russia, which granted Cyprus a loan of 2.5 billion dollars.

There are still numerous Russian companies based in Cyprus, although there is a lot of pressures on Russian companies to repatriate assets while Russian-related businesses are believed to make up around $10 \%$ of the Cypriot economy. Most of them are located in Limassol, where a Chamber for Russian Companies, Russian schools, and Orthodox Churches have been founded as well as a Russian-language television and radio service have been set up. Cypriot law allows those who buy a house worth 300,000 euros to claim permanent residency rights, while those who spend five million euros or more on property can apply for passports. According to an estimate by Morgan Stanley Cypriot entities, often owned by rich Russians, lent 40 billion US dollars a year to Russia from 2007 through 2011. About 25\% of Russian foreign direct investment moves through Cyprus, frequently in a "round-trip" process that serves to lubricate the Russian economy (Kramer, 2013).

Moreover, there has been serious Russian interest in developing Leviathan, either alongside existing partners or in the event of pulling out Noble Energy, the US company conducting the drilling in the region, of the project. This raises the prospect of Russia pushing for a field development program focused on Floating Liquefaction Natural Gas (Ellinas, Roberts, \& Tzimitras, 2016, p. 3).

\section{Russia's Policy in Syria and Implications for the EU and Regional Players}

The war in Syria constitutes the second field of competition between EU countries and Russia, due to the 
latter's support for the Assad regime, which escalated into Moscow's active military engagement. The Russian military intervention in the Syrian Civil War began on 30 September 2015, following, according to media reports, a formal request by the Syrian government for military helps against rebel and jihadist groups. The activities consisted of air strikes primarily in north-western Syria against militant groups opposed to the Syrian government. A quarter-century after its withdrawal from Afghanistan, Moscow found itself again at war in a Muslim country outside of the perimeter of its historical empire.

The war in Syria had many side effects, as it affected the fragile geopolitical architecture of power in the region in many ways. The most radical change has been precipitated by the Russian-Turkish clash. Already, in October 2014, Ankara had illegally issued a NAVTEX order, thereby reserving areas in the Economic Exclusive Zone of the Republic Cyprus for seismic surveys, and dispatched a seismic vessel accompanied by Turkish warships in order to collect data. In reprisal, Greece, the Republic of Cyprus, and Israel, this time with Russian participation, conducted a joint naval exercise in waters of the Eastern Mediterranean on the same days. Once again, it became salient that no matter how important the US role in the region might be, all of the countries still need Russian diplomatic and military support. It was the first episode (Moscow threatened Turkey with counter-action should it continue its naval activity there) in a gradual deterioration in Ankara-Moscow relations that was to culminate in the context of the Syrian crisis.

Clouds over Turkish-Russian relations had already appeared during the 2014 Russian invasion of the Crimean Peninsula where roughly 300,000 Turkic-speaking Tatars still remain as a remnant of Ottoman history. The ensuing annexation of Crimea shifted the balance of power in the Black Sea at Turkey's expense. After the annexation of Sevastopol, Russia's Black Sea Fleet, largely designed to counter Turkey's naval strength in wartime, can be deployed at whim in the Black Sea. To supply its forces in Syria, the Russian navy has been relying on the so-called Syrian Express, a naval supply route from Sevastopol on the Black Sea to its Eastern Mediterranean naval facility at the Syrian port of Tartus. However, according to Article 20 of the Montreux Convention, which stipulates that in wartime, Turkey as a belligerent has full discretion when allowing or preventing the passage of warships through the strait, potentially cutting Russia off from the Mediterranean. Therefore, Russia has been pushing for decades for a revision of the respective treaty. ${ }^{4}$

Russia's annexation of Crimea in March and continuous action to support Eastern Ukraine's anti-government forces, including alleged direct Russian military support for separatist militias in the Donbass region, did radically change not only the Ankara-Moscow relationship but also the whole Post-Cold War paradigm of European security. Throughout the first half of 2014, it also urged Western governments to recognize that the two-decade policy of courting Russia as a partner in building Euro-Atlantic security had failed, and that a shift back to a more adversarial relationship was under way (The Military Balance, 2015, pp. 57-58).

Accordingly, NATO initially condemned Russian air strikes and urged Russia to stop supporting Syrian President Bashar al-Assad. However, after the terrorist attacks in Paris and the invoking of the Article 42.7 of the NATO-alliance charter by France, a rapprochement between Western Countries and Putin toward ISIS began to emerge. And yet, suddenly on 24 November 2015, a Russian Sukhoi Su-24 aircraft was shot down by a Turkish Air Force F-16 fighter jet in an incident thought to be the first time a NATO country shot down a

\footnotetext{
${ }^{4}$ Personal Communication with the Sabanci University Professors of International Relations Ahmed Evin and Meltem Müftüler-Bac (Istanbul September 2014.
} 
Russian plane in half a century. Notably, the incident triggered an open confrontation between Russia and Turkey (Moscow imposed rigid sanctions against Turkey including imports of Turkish farm and other products, the non-extension of contracts for the 200,000 Turks working in Russia, a ban on Turkish companies in Russia and an end to charter flights between the countries), negatively affecting a possible NATO-Russia cooperation.

Turkey has already demanded backing from its NATO allies towards Syria in the summer of 2012, after Syrian troops shot down a Turkish warplane. Consequently, it called for a convention of NATO members under Article 4 of the organization's charter, which provides for consultations, when a member state feels its territorial integrity, political independence, or security is under threat (Stergiou, 2013). By shooting down the Russian airplane, Turkey signaled that it wanted action to be taken in Syria only under its supervision, enabling Ankara to put its terms in the post-war architecture of power in the region.

Over the past a few decades, Turkey's focus has been on northern Syria and northern Iraq, a belt of former Ottoman provinces that naturally extend eastward from Turkey's Hatay province and is mostly populated by Kurds. Russia's involvement in Syria in defense of the Alawite government runs directly against Turkey's objective of expanding its own military footprint in Aleppo, keeping under control the Kurdish separatist activity probably by creating a "free stateless zone" and eventually replacing Syrian President Bashar al Assad with a Sunni government friendly to Turkish interests. Yet, this does not comply at all (to that extent for the first time since Turkey was incorporated into the North Atlantic alliance) with Western interests. Western countries have been heavily relying on Kurds and seeking Russian assistance in resolving the Syrian question (Centre for Eastern Studies Analyses, 2016).

However, Turkey and the EU have a very serious problem in common linked to the Syrian war, the huge wave of refugees. The military successes of Assad's forces backed by the Russian Federation in northern Syria in the first months of 2016 increased the number of refugees on the Turkish border and the threat of another wave of migration from the Middle East to the EU. The Assad regime's military successes mean that it is more and more likely that it will recapture the territories currently controlled by the opposition forces supported by Turkey. At the same time, Syrian Kurd troops and the Islamic State, both of which are hostile towards Ankara, have maintained their positions in northern Syria. If Assad's troops manage to reach the Turkish border, this will mean the elimination of Ankara's and the West's proxies in this part of the country, and Turkey's real influence will be dramatically reduced (Centre for Eastern Studies Analyses, 2016).

On the other side, Russia seems to have multiple incentives, which are still in stark contrast to those of its Western "allies", to get involved in the war. Perhaps, the most important one is to strategically divert the West from Russia's primary interests in Europe, that is, Russian predominance in East-Central Europe. It obviously wants Assad to remain in power and to use the conflict instrumentally in order to improve the Kremlin's bargaining position in its relations with the West.

More specifically, the Syrian campaign was Moscow's attempt to retain the domestic prestige it won with the annexation of Crimea and to break out of the external siege that was laid by the West immediately afterwards by trying to fit into the new global order as a great power. The deployment of the highly advanced S-400 missiles notably does not comply with the scale of the military anti-rebels operations undertaken so far in Syria. However, they demonstrate, together with the increased Russian military personnel and heavy equipment (T-90 tanks, armoured personnel carriers, artillery systems, and surface-to-air missiles), Russia's military strength. As has been observed, Russia's new military boldness and adventurism have left Western observers puzzled (Gressel, 2015, p. 1), but it does not come out of nowhere: current Russian strategy is the culmination 
of a systematic military reform that has been insufficiently appreciated by the European Union and the US. Russia has implemented far-reaching military reforms to create a more professional and combat-ready corps of armed forces that can swiftly deploy abroad, backed by expertise in non-conventional warfare tactics such as subversion and propaganda.

Another very significant incentive for Moscow's military tactics is apparently the Muslim population of 20 million currently living in Russia, which is $40 \%-50 \%$ larger than in 1989 and increasingly radicalized. It is widely predicted that at these rates, the majority cohort in the Russian Armed Forces will be Muslim by 2020. Despite its diplomatic offensives (notably after September 2001 and today), Moscow does not share Washington's commitment to a "global war on terrorism". However, it does wish to keep jihadis out of Russia and the former USSR (Clingendael, 2015, pp. 69-71).

For the Russians, ISIS constitutes a mortal enemy for two main reasons. First, it is a global jihadist organization that looks to all Muslim-populated areas, including Central Asia and Russia's own North Caucasus, Tatarstan, and others. Second, a large proportion of its foreign fighters originated from former Soviet lands and from Russia itself. Once victorious in Syria and Iraq, these jihadis can move to their places of origin and start making trouble there (Carnegie, 2015a).

Last but not least, as has already been mentioned, the prospecting energy 25 -year deal Russia signed at the end of 2013 with the Damascus' regime might be another incentive for Russia's involvement in the Syrian war.

Against this background both the 22 February 2016 Russian-American declaration on Syria for a ceasefire and the 9 September 2016 US-Russia agreement to reduce violence in the Syrian conflict should be regarded as a diplomatic success for the Kremlin. Even though the declaration did not bring about any resolution to the conflict and even though it is highly uncertain that joint military targeting by the two powers against Islamic jihadists in Syria agreed in September 2016 will work out, both earned Russia the formal recognition of its role as a co-decision maker in resolving the Syrian question. Moreover, the failure of the agreements in themselves will make it difficult for the West to criticize Russia's and Assad's tactics in the conflict. Russian Federation's foreign minister Lavrov's comment on the agreement that "it denounces arrogant sanctions" levied against Russia for its annexation of Crimea two years ago, speaks volume for the role Syria's conflict plays in Kremlin's strategy (Center for Eastern Studies, 2016; Sanger \& Barnard, 2016).

The temporary crisis between Turkey and Russia had an impact on the regional energy balances as well. Given Turkey's dependence on Russian energy resources, Ankara turned back to Israel seeking alternative energy suppliers and new routes. As a gesture of good will towards Turkey's reconciliation with Israel, in May 2016, Ankara enabled Israeli activity within NATO, and permited Israel to open an office in NATO headquarters. This move did not come out of the blue. Meanwhile, the tripartite Greece-Cyprus-Turkey energy cooperation is viewed skeptically by energy experts. Israel is uncertain how much gas it will eventually have, whether it will be able to export it, to whom, or by what means. Talks with Greece and Cyprus about gas have been going on for several years without any real results. It is conceivable in principle to build a pipeline connecting the three countries, but it would be very complicated from a technical standpoint, and would cost almost 10 billion dollars (The Begin-Sadat Center for Strategic Studies-BESA, 2016). Publicly, the three countries have been repeatedly announcing that they mull constructing shared infrastructure for gas export, in fact however Cyprus and Israel are competing to export gas to other countries. Furthermore, Israel can prevent Cyprus from exporting its Aphrodite gas to Egypt and Cyprus can prevent Israel from exporting its Leviathan stock to Turkey. 
The Aphrodite reservoir, discovered in Bloc 12 in Cypriot waters, partly extends into Israeli territorial waters. This has been complicating Israel-Cyprus' joint development of the reservoir by delaying the signing of a unitization agreement. The two parties have been disputing since 2010 over the quantity of gas in Israeli territory and Israel's level of involvement in the reservoir's development. Meanwhile, Israel refuses to sign a unitization agreement between the states to formally delineate the developments of natural gas and oil reserves shared by the pair which delays the development of the reservoir (H. Cohen, 2016).

US-mediation in the Ankara-Tel Aviv dispute seems to have been aimed at facilitating the pro-Western monetization of Mediterranean gas along the lines of constructing a pipeline from Israel to Turkey. That option, however, presupposes a settlement of the Cyprus conflict or at least an improvement of the bi-communal relations, as the pipeline would pass through the internationally recognized Exclusive Economic Zone of Republic Cyprus. Such a unilateral move by Tel Aviv, however, could complicate things further, as it would amount to recognition of the Turkish Republic of Northern Cyprus, only recognised by Turkey, and torpedo Israel-Cyprus relations for good.

Eventually, in June 2016, Israel and Turkey reached a deal to normalise their fraught relations. Except the important economic and energy considerations the turn Syria war has got must be regarded as an additional incentive behind this development. It is widely known that Israel is deeply concerned with limiting the regional influence of its arch-foe Iran, while Turkey and Iran, though cooperating in various sectors, have been remaining on opposing sides of the five-year civil war in Syria.

Similar factors (the revival of projects such as the natural gas pipeline, Russia's contract to build Turkey's first nuclear power plant, and Syria Civil War) appeared to be among the incentives, which entailed the rapid improvement of Turkey-Russian relations in Summer 2016. It is no accident that Erdogan's first foreign trip since the abortive July 15 putsch in Turkey was to Russia just as Turkey's relations with traditional allies the United States and Europe showed once again increasing strain. However, the rapprochement is far away from being a strategic relationship, as Erdogan and Putin attempted to depict it, or an unholy alliance based on common authoritarian perceptions, as in a naive approach was labelled by the Western press. It is rather a fragile cooperation of convenience driven by mutual interest, which offers to the both sides leverage to negotiate with the US and the EU open questions: Ukraine, refugees, EU-Turkey relations, and the day after in the Syria War.

Similar factors (the revival of projects such as the natural gas pipeline, Russia's contract to build Turkey's first nuclear power plant, and Syria Civil War) appeared to be among the incentives which entailed the rapid improvement of Turkey-Russian relations in Summer 2016. It is no accident that Erdogan's first foreign trip since the abortive July 15 putsch in Turkey was to Russia just as Turkey's relations with traditional allies, the United States and Europe showed once again increasing strain. However, the rapprochement is far away from being a strategic relationship, as Erdogan and Putin attempted to depict it, or an unholy alliance based on common authoritarian perceptions, as in a naive approach was labelled by the Western press. It is rather a fragile cooperation of convenience driven by mutual interest, which offers to the both sides leverage to negotiate with the US and the EU open questions: Ukraine, refugees, EU-Turkey relations, and the day after in the Syria War. The fact, however, that Moscow has been tolerating Turkey's military operation (Euphrates Shield) into the territory of Syria since August 2016, foreshadows a further increase in tension around strategic issues between Turkey and the NATO. Moscow's motive behind this cooperation appears to be the same, it has destined its strategy all the years before in the region, to encourage a strategic separation between Ankara and Western countries. 
It could be very significant, however the repercussion is on the energy geopolitics of the Eastern Mediterranean. Ankara has been aiming for the first transfer of Israeli gas to take place by 2020, but Russia's aggressive foreign policy towards Turkey posed a significant challenge to the East Mediterranean pipeline. Indeed, by building up its presence in the East Mediterranean (in September 2015, the Russian military began expanding its tiny naval facility at Tartus on the Syrian coast to handle bigger warships and transport vessels), Russia might have a word in the energy architecture and redouble its diplomatic-military maneuvers in and around the region, including establishing more bases for naval operations (Cropsey \& Brown, 2014, p. 30; Varol, 2016).

\section{EU's Response to the Financial and Debt Crisis of Greece and Cyprus and Its Impact on EU-Russia Antagonism}

The radical left-wing SYRIZA political party's rise to power in January 2015 added a new imponderable factor to Eastern Mediterranean power politics. Statements by party members appeared to be clearly directed against the Eurozone and NATO membership. They were also against foreign military bases in Greece - including allowing the US to remain - and extremely pro-Russian. Nevertheless, the Greek Left's apparently favorable attitude towards President Vladimir Putin's Russia turned out to have serious ramifications on Country's domestic and external course.

Especially SYRIZA's current coalition partner and previous passionate bail-out policy opponent, the right-populist party, Independent Greeks, has been feeling comfortable with Putin's ideology of traditionalist nationalism, social conservatism ${ }^{5}$, and religious affiliation contrary to SYRIZA's deep-rooted atheism. Pro-Russian views are popular in broad parts of the Greek society. In May 2014, for instance, almost six out of 10 Greeks disagreed with the EU's initiative to impose economic sanctions to Russia over the Russian invasion to Ukraine issue (Rettman, 2015). There is a widespread perception in Greece that it shares common religious convictions and political and cultural roots in history with Russia as well as common economic and political interests and many Greek foreign policy analysts, the foreign minister of Greece in the SYRIZA-led government Kotzias (2010) also among them, have argued that closer ties with Russia should be part of a multi-dimensional Greek foreign policy.

Many Greeks were opposed to the rescue package for Greece linked to harsh austerity measures imposed by the European Union, the European Central Bank, and the International Monetary Fund, and hoped that the Greek government in 2010 would consider a loan from Russia instead. But when Greek Prime Minister George Papandreou visited Moscow, Vladimir Putin advised him to go to the International Monetary Fund (IMF) for funding and Greece had no other choice but to accept the EU and IMF's bailout-policy. The backstage story seems to be that Papandreou was not prepared to upset the US by helping Russia to revive the Burgas-Alexandroupolis oil pipeline and that Putin reciprocated.

The SYRIZA-led government's perceptions on Greece's real potential in the international arena and bargaining capacity towards Greece's creditors proved soon to be naive and unrealistic. The more the Europeans did not yield to leftist demands for a revision of the bail-out policy towards Greece and a writing-off of the latter's sovereign debt, the more intensively Athens attempted to show Europeans that it could turn east, playing Russia off against the EU. Therefore, it repeatedly denounced international sanctions against Moscow

\footnotetext{
${ }^{5}$ Party's president Panos Kamenos immediately after the shooting down of the Russian airplane in Syria appeared in the Greek Television blasting Turkey and calling NATO to take into consideration Russia's accusations against Turkey!
} 
in the wake of the war in the Ukraine as harmful for Europe and counter-productive for EU strategy, security and foreign policy, formulating instead the opinion that the Ukraine should be a bridge between the EU and Russia, not an area of division (Rettman, 2015; EUvox Voting Advice Application Data, 2014).

Relying on Greece's history in the Western Camp after the Second World War, Athens tried once again to exploit its important and very sensitive for Western interests geo-strategic position. During the Cold War, Greece's location on NATO's southeastern flank was a powerful trump card to extort military and economic aid to prevent Greece from falling under the influence of the Soviet Union. This was the rationale behind the Truman Doctrine and for some parts also the Marshall Plan. Invoking a possible state of collapse, given the tremendous flood of migrants to Europe and Russia's non-compliance with EU policy in the Eastern and South-Eastern Europe, was perceived as an unbeatable diplomatic tool to enhance the country's bargaining leverage in its competition with EU institutions. Notably, in April 2015, the Greek Prime Minister Alexis Tsipras traveled to Moscow. Since he was the first European leader to travel there since the assassination of Boris Nemtsov, his visit led to nervousness in Brussels and in the European Capitals (Rappold, 2016, p. 2) and provoked strong criticism by Western analysts that his trip might make him a "useful idiot" for Moscow and Putin, who was isolated at that time. The aim of the visit was to confirm a possible multibillion-dollar pipeline deal - the resurrection of the Russian-sponsored South Stream project under the new name, Turkish Stream. Greek officials had negotiated the deal a few weeks earlier with the head of the Russian energy giant Gazprom, ahead of the European Union's announcement about antitrust charges against Gazprom and the company's determination to stop gas transit through Ukraine after 2019. As it shall see, Tsipras' visit came to nothing substantial, since he was clearly not prepared to upset NATO or Brussels.

This move could also be considered as fierce provocation against Brussels and its adoption on 25 February 2015 of the so-called Framework Strategy for a Resilient Energy Union With a Forward-Looking Climate Change Policy, to date the most significant development in plans for an EU-wide Energy Union. With the Energy Union the EU countries intend to facilitate cross-border coordination and integration in energy security, trade, regulation, and efficiency, as well as in low-carbon development and research and innovation (European Commission, 2015). The war in Ukraine and the following Russia's annexation of Crimea in early 2014 have consequently prompted efforts to coordinate the diversification of energy supplies.

Given the fact that Greek territory has already been chosen for the Trans-Adriatic pipeline (TAP) to deliver gas from Azerbaijan to the European market, this deal could have serious political implications. In May 2016, Greece launched construction on a 550-kilometre (342-mile) section of the Trans-Adriatic Pipeline, which is planned to operate from 2019. The so-called Trans-Adriatic pipeline, which beats out competition from the Nabucco West project, being developed by Norwegian, Swiss, and German companies and hence favored by the EU, is expected to cross the territory of Greece and Albania reaching across the Adriatic Sea in Italy, carrying about 10 billion cubic meters per year to European markets. Once the pipeline is completed, Gazprom will lose its monopoly in southern Europe and may have to resort to price dumping to stay competitive. But even Gazprom's position in the European gas market is becoming less and less secure. Gas production in Europe has been falling, but net imports of gas are dropping even faster: net imports fell from 299 billion cubic meters in 2010 to 219 billion cubic meters in 2014, with just a slight uptick in 2015 deviating from the long-term trend (Carnegie, 2016).

Therefore, Russians have offered the possibility of 47 cubic meters of Russian gas, which could arrive through Turkish Stream to the Greek border and it looks obviously much more profitable than the 10 cubic 
meters of Azeri gas to be pumped through the TAP pipeline. However, Greece's European creditors were strongly opposed to the deal. Thus, as has been the case with the South Stream pipeline, envisioned initially as running through another EU country, Bulgaria, such a deal could circumvent EU antitrust legislation (Gazprom had invested between $\$ 14$ billion and $\$ 17$ billion in the South Stream project without receiving the necessary approvals from EU oversight bodies and the company did not even file for them). Furthermore, the prosed pipeline, meant to carry Russian gas to Europe through Turkey and Greece, would therefore face strong political objections by the EU-institutions (The finnish institute of International Affairs, 2015, pp. 6-7).

According to Greek media reports in July 2015 (Papadopoulos, 2015), it was denied by the Kremlin but urged 17 lawmakers from the opposition to officially ask Greek Government in parliament whether the reports were true, Greek Prime Minister Alexis Tsipras asked Putin without success for a 10 billion US-Dollar loan so that Greece could reintroduce the national currency to reject EU-institutions conditions for a new bail-out package for its ailing economy. The idea behind the request seems to have five billion US-dollars advance on the construction of the Greek branch of the Turkish Stream gas pipeline. ${ }^{6}$

According to rumours, Tsipras' first telephone call outside Greece after the 5 July bailout referendum rejecting the final rescue-package proposed to Greece by its creditors, was to Russian President Vladimir Putin, in order to ask him for just one billion euros in the form of short-term bonds or investments in future construction projects, to keep the liquidity in the Greek banks afloat. Again, he was politely rebuffed. On the contrary, Putin has not even relaxed the counter-sanctions on Greek vegetables and fish in the six months of SYRIZA's administration.

If the estimation made by some scholars (Bershidsky, 2015) is true, that Russia, despite low oil prices, still had at that time more than $\$ 360$ billion US-dollars in foreign reserves, the Kremlin could easily have provided the $\$ 10$ billion US-dollars financial help to Greece. Apparrantly, Moscow is led by pragmatist realpolitik-motives, rather than simply Christian Orthodox solidarity, as many believed in Greece, and it prefers not to give money to anybody, unless it can get something tangible in return, something Athens was unable to do.

Some observers (Carnegie, 2015b) have argued that the situation would be different if Greece had left the Eurozone with all its debts written off or if the Russian economy was better. Then, Russian loans could have been used to strengthen a new currency, making it cheaper and more profitable for Russia to acquire and develop Greek assets. There is also another very plausible interpretation for the Kremlin's behaviour in line with Moscow's penetration history in the region. Russia acted in this manner just to gain political benefits from the Greek crisis, by trying to exploit rifts and fissures in European unity. Moscow lets the Europeans look weak and bad so as to have a Russia friendly country within the EU to use it as a lobbying and communication channel.

The NATO summit in July 2016 confirmed that estimation. As it was leaked into press (see Financial Times July 10, 2016) Greek Prime Minister Alexis Tsipras was the only of the NATO heads of state to break form the official consensus and urged the leaders of the 28-member transatlantic alliance to end the stand-off with Moscow arguing rather for partnership with Vladimir Putin, the Russian president to end the crisis in Syria, only to draw a reaction from US President Barack Obama. It was not the only thing raising concerns to the NATO officials. A few weeks earlier, after Putin had once again paid an official visit to Greece attempting a

\footnotetext{
${ }^{6}$ According to Yuri Kvashnin (Head of Section of the EU Studies of the Institute of World Economy and International Relations of the Russian Academy of Sciences), there was not such a request (Yuri Kvashnin, personal communication, September 4, 2015).
} 
charm offensive, the Greek defence minister, Panos Kammenos, unveiled a new defence deal with Russia to manufacture Kalashnikov rifles! Greek government's official explanation was that the deal is vital to prevent the collapse of the country's defence industry (Coughlin, 2016).

Only two years earlier, Russia's approach had been repeated in Cyprus, despite the very close Cypriot-Russian economic and political ties. The haircut in Greek sovereign debt in the spring of 2012 brought about heavy losses in Cypriot banks, forcing the government in Nicosia to raise fresh money in order to recapitalize the island's banking sector. As it was still excluded from the bond markets, Nicosia turned again to its partners in the European currency union for financial aid, considering itself unfairly treated by the EU decision to restructure Greece's debt, as it had coerced Cypriot banks into writing off around $80 \%$ of the value of their Greek bond holdings. In Nicosia's opinion, the write-down of Greece's debt should have been distributed on the basis of the size of each Eurozone economy, of which Cyprus makes up just $0.2 \%$. Nevertheless, the European Central Bank, European Commission, and International Monetary Fund, together known as the "troika", were willing to grant that assistance only within the context of a bailout program, which entailed much stricter conditions than the loan it had so far taken from Moscow. The Communist Progressive Party of Working People (AKEL) government in Nicosia decided then to again ask Moscow for a five billion euros' loan in order to avoid a similar harsh rescue package designed by the EU and the IMF, but received a categorical refusal from the Kremlin. ${ }^{7}$

Consequently, Nicosia was compelled to accept an unprecedented haircut on deposits in Cypriot banks, resulting in a big loss of money for the overwhelming majority of Cypriot citizens and of wealthy Russians and Russian multinational corporations who possessed uninsured deposits of above 100,000 euros. According to an estimate by Moody, the rating agency, Russian deposits in banks and loans to Cypriot companies amounted to 70 billion US dollars, or about $4 \%$ of Russia's gross domestic product at that time. Some $42 \%$ of the value of Cypriot bank deposits were in accounts with more than half a million euros (Kramer, 2013).

Cypriot leaders were apparently so concerned with keeping their wealthy offshore Russian customers happy that they pushed their own citizens to pay even more than some of the lenders were demanding. The huge amounts of Russian money, deposited at that time in Cypriot banks, seemed to be a thorn in Europeans flesh. Although until then Cyprus bank system according the 2011 Report by the Committee of experts on the evaluation of anti-money laundering measures and the financing of terrorism (MONEYVAL), was perceived to cope with all the anti-money laundering and the criminalisation of the Financing of Terrorism standards, it was targeted over night as a money-laundering machine (Council of Europe, 2011). Meanwhile, the source of Northern European countries' reluctance to rescue the Cypriot banking sector was revealed: a confidential report by the German foreign intelligence agency, the Bundesnachrichtendienst, had painted the island a few months ago as a haven for money-laundering (Der Spiegel, 2012).

In a paradoxical way, what the European leaders engineered, obviously intending to end an economic model fuelled by a flood of cash and "dirty money" from Russia, turned out to backfire. As the bail-in provided that the levied money should be exchanged with equities in the share capital of the bank, the EU strategy pulled

\footnotetext{
${ }^{7}$ Wealthy Russians and big companies affiliated to Kremlin have had their money in Luxembourg or in Netherlands, as Cyprus has always been perceived in Russia as a dangerous place to have money. Moreover Kremlin was able in this manner to punish those companies preferring to pay their corporate taxes abroad and not within the Russian Federation. There are also many rumors that many Russian people managed to repatriate their money through the Uniastrum Bank (LLC) which was founded in 1999 (Yuri Kvashnin, personal communication, September 4, 2015).
} 
Russia even deeper into Europe's financial system by giving its plutocrats ${ }^{8}$ majority ownership, at least on paper, of the Bank of Cyprus the country's oldest, biggest, and most important financial institution (Higgins, 2013), but it is another story.

\section{Conclusion}

The objective of this study is to analyse aspects of Russia's defence and energy strategy in the Eastern Mediterranean, a region characterized by a remarkable, ongoing reconfiguration in the balance of power in recent years. Russia's foreign policy has been deployed in the framework of the EU-NATO-Russian antagonism surrounding mainly energy and security that have been raging in the wider region since the 1990s. Exploiting the rifts and the conflicts repeatedly emerged among the regional players in the last decade, Moscow tried to fill the economic and security vacuum opened every time up, Kremlin managed to maintain a delicate, low-key, and balancing strategy with its policies and to a longer, and more nuanced game in the region than perhaps any other player in the Post-Cold War. Two elements compose overall Russian strategy in this region, energy and military involvement. The energy factor is used to secure Russia's hegemonic position as traditional energy supplier of the West and as potential energy supplier of China that has been seeking meanwhile to pave a new Silk Road through the region.

Russia's military involvement has two dimensions, the enhanced defence cooperation Kremlin has pursued with most of the countries of the region and the Syrian campaign. The latter was Moscow's attempt to retain the domestic prestige it won with the annexation of Crimea and to break out of the external siege that was laid by the West immediately afterwards by trying to fit into the new global order as a great power. The deployment weapons that do not comply with the scale of the military anti-rebels operations undertaken so far in Syria, have been meant to demonstrate Russia's military strength and present the country as an alternative security provider in this unstable region.

\section{References}

Begin-Sadat Center for Strategic Studies. (2011). Eurasian energy and Israeli choices. Tel-Aviv: Ariel Cohen \& Kevin DeCorla-Souza.

Bershidsky, L. (2015). Did putin sell out greece? Bloomberg. Retrieved from https://www.bloomberg.com/view/articles/2015-07-22/did-putin-sell-out-greece

Carnegie. (2015a). Putin's Syria gambit aims at something bigger than Syria. Moscow: Dmitri Trenin.

Carnegie. (2015b). Why Moscow opposed Grexit. Moscow: Alexander Baunov.

Carnegie. (2016). The new pipeline making Gazprom nervous. Moscow: Mikhail Krutikhin.

Central Bank of Cyprus. (2002). Monetary policy report.

Centre for Eastern Studies Analyses. (2016). Turkey and the EU: The play for a security zone in Syria. Warsaw: Krzysztof Strachota/Mateusz Chudziak.

Centre for Eastern Studies. (2013). Russian army justifies its reforms. Warsaw: Andrzej Wilk.

Centre for Eastern Studies. (2014). The unwanted gas pipeline: Russia has halted the construction of south stream. Warsaw: Szymon Kardaś.

Centre for Eastern Studies. (2016). The Russian-American declaration on Syria: A success for Moscow. Warsaw: Marek Menkiszak.

Clingendael. (2015). The new east-west discord. Russian objectives, western interests. The Hague: James Sherr.

Cohen, H. (2016). Israel, Greece, Cyprus mull joint natural gas projects. Globes Israel Business Arena. Retrieved from http://www.globes.co.il/en/article-israel-greece-cyprus-mull-joint-natural-gas-projects-1001119233

\footnotetext{
${ }^{8}$ According confidential information the Author collected in Moscow, some of the biggest stakeholders in the Cypriot Banks are the Renova Group owned by Viktor Vekselberg and Vladimir Strzhalkovskiy who are supposed to be Putin's confidante.
} 
Cohen, J. (2016). Vladimir Putin is the closest thing to a friend Israel has ever had in Moscow. Reuters. Retrieved from http://blogs.reuters.com/great-debate/2016/01/14/vladimir-putin-is-the-closest-thing-to-a-friend-israel-has-ever-had-in-mosco w/

Coughlin, C. (2016). Nato's united front under threat after Greece signs arms deal with Russia. The Telegraph. Retrieved from http://www.telegraph.co.uk/news/0/natos-united-front-under-threat-after-greece-signs-arms-deal-wit/

Council of Europe-ECRI REPORT ON CYPRUS. (2011). Retrieved from http://www.coe.int/t/dghl/monitoring/ecri/country-by-country/cyprus/CYP-CbC-IV-2011-020-ENG.pdf

Cropsey, S., \& Brown, E. (2014). Energy: The West's strategic opportunity in the Eastern Mediterranean. Washington, D.C.: Hudson Institute.

Der Spiegel. (unknown author) (2012). Russische Schwarzgeldkonten: BND warnt vor Rettungspaket für Zypern. Retrieved from http://www.spiegel.de/wirtschaft/soziales/russisches-schwarzgeld-bnd-warnt-vor-rettungspaket-fuer-zypern-a-865151.html

Eksi, M. (2010). The role of energy in Turkish foreign policy. The Turkish Yearbook of International Relations, 41, 59-69.

Ellinas, C., Roberts, J., \& Tzimitras, H. (2016). Hydrocarbon developments in theeastern mediterranean the case for pragmatism. Atlantic Council.

European Commission. (2015). Energy Union: Secure, sustainable, competitive, affordable energy for every European. Retrieved from http://europa.eu/rapid/press-release_IP-15-4497_en.htm

EUvox Voting Advice Application Data. (2014). Retrieved from http://www.euvox2014.eu/?page_id=363

Fabry, N., \& Zeghni, S. (2002). Foreign direct investment in Russia: How the investment climate matters. Communist and Post-Communist Studies, 35(3), 289-303.

Fondazione Eni Enrico Mattei Institute. (2013). Towards a new Eastern Mediterranean Corridor? Natural gas developments. Between market opportunities and geopolitical risks. Rome: Simone Tagliapetra.

Gressel, G. (2015). Russia's quiet military revolution and what it means for Europe. London: The European Council on Foreign Relations.

Günaydin, E. B. (2014). Can South-Eastern Mediterranean gas be a supply for the EU? Istituto Affari International Paper, 17, 5-6.

Higgins, A. (2013). Cyprus bank's bailout hands ownership to Russian plutocrats. New York Times. Retrieved from http://www.nytimes.com/2013/08/22/world/europe/russians-still-ride-high-in-cyprus-after-bailout.html?_r=0

Inan, Y., \& Gözen, P. M. (2009). Turkey's maritime boundary relations. In Mustafa Kibaroglu (Ed.), Eastern Mediterranean countries and issues (pp. 153-211). Ankara: Foreign Policy Institute.

Jacques Delors Institute. (2013). The role of gas in the external dimension of the EU energy transition (Notre Europe Policy Paper 79). Bruxelles: Andoura Sami \& Clémentine D'Oultremont.

Jarosiewicz, A. (2015). The Southern gas corridor. The Azerbaijani-Turkish project becomes part of the game between Russia and the EU. Points of View No. 53. Warsaw: Centre for Eastern Studies.

Kotzias, N. (2010). Greece's foreign policy in the 21st century (in Greek). Athens: Kastaniotis-Publisher.

Kramer, A. (22). Wealthy Russians ensnared as cyprus crisis deepens. New York Times. Retrieved from http://www.nytimes.com/2013/03/23/business/global/wealthy-russians-ensnared-as-cyprus-crisis-deepens.html

Liuhto, K., \& Majuri, S. (2014). Outward foreign direct investment from Russia: A literature review. Journal of East-West Business, 20(4), 198-224.

Makarychev, A. S. (2009). Russia in the Mediterranean Region: (Re)sources of Influence. The Yearbook of The European Institute of the Mediterranean (IEMed), 169-172.

Papadopoulos, P. (2015). Leonid, Alexis and Panagiotis. To Vima-newspaper (In Greek). Retrieved from http://www.tovima.gr/politics/article/?aid $=723482$

Pelto, E., Vahtra, P., \& Liuhto, K. (2003). Cyprus investment flows to Central and Eastern Europe-Russia's direct and indirect investments via Cyprus to CEE. Turku: Turun Kauppakorkeakoulu-Turku School of Economics and Business Administration.

Pilides, P. (2002). The role of Cyprus in inward investment in Russia, Central and Eastern Europe. Cyprus: Pricewaterhouse coopers.

Rappold, J. (2016). In search of alternatives. Greece between European frustration and Russian temptation, DGAP Kompakt 3 (German Council of $\quad$ Foreign $\quad$ Relations), $\quad 1-8 . \quad$ Retrieved from https://gap.org/en/think-tank/publications/dgapanalyse-compact/search-alternatives

Razumovskaya, O. (2015). Cyprus signs deal to let Russian navy ships stop at its ports. Wall Street Journal. Retrieved from http://www.wsj.com/articles/putin-highlights-closer-russia-cyprus-ties-1424882012 
Ren, J., Tan, S., Goodsite, M. E., Sovacool, B. K., \& Dong, L. (2015). Sustainability, shale gas, and energy transition in China: Assessing barriers and prioritizing strategic measures. Energy, 84, 551-562.

Rettman, A. (2015). Greece says No to EU statement on Russia. EUobserver. Retrieved from https://euobserver.com/foreign/127393

Sanger, D., \& Barnard, A. (2016). Russia and the United States reach new agreement on Syria Conflict. New York Times. Retrieved from http://www.nytimes.com/2016/09/10/world/middleeast/syria-john-kerry-ceasefire-deal-russia.html?_r=0

Sener, A. (2006). Turkish-Russian Relations after the Cold War 1992-2002. Turkish Studies, 7(3), 337-364.

Shaffer, B. (2009). Energy politics. Philadelphia: University of Pennsylvania Press.

Siman, B. (2016). Russia seizing initiative in Eastern Med. Geopolitical Inteligence Service Report. Retrieved from https://www.gisreportsonline.com/russia-seizing-initiative-in-eastern-med,defense, 1879, report.html

Stergiou, A. (2011). Les Russes à Chypre dans l'après-Guerre Froide. Outre-terre. Revue européenne de géopolitique, 27, 121-128.

Stergiou, A. (2012). Russian policy in the eastern Mediterranean and the implications for EU external action. European Union's Institute for Security Studies (ISS)-online-publications-opinions.

Stergiou, A. (2013). Geopolitics: Greece, Cyprus and Israel change the military balance in the Mediterranean. Geopolitical Intelligence $\quad$ Service. $\quad$ Retrieved from https://www.gisreportsonline.com/greece-cyprus-and-israel-change-the-military-balance-in-the-mediterranean,politics, 644 .ht $\mathrm{ml}$

Stergiou, A. (2015). Greek-Israeli defense and energy ties: Writing a new chapter in bilateral relations. Israel Journal of Foreign Affairs, 9(3), 417-428.

Takin, A., \& Williams, P. A. (2011). Geo-Politics of the Euro-Asia energy nexus. The European Union, Russia and Turkey. Basingstoke, Hampshire: Palgrave Macmillan.

The Begin-Sadat Center for Strategic Studies-BESA. (2016). A New Geopolitical Bloc is born in the Eastern Mediterranean: Israel, Greece and Cyprus. Tel-Aviv: Mekel Arye.

The Finnish Institute of International Affairs. (2015). The EU-Russia gas relationship. New projects, new disputes? (Briefing Paper 183). Helsinki: Marco Siddi.

The Military Balance. (2015). Chapter Four: Europe, 115(1), 57-158.

Van der Puten, F. P. (2016). Infrastructure and geopolitics: China's emerging presence in the eastern Mediterranean. Journal of Balkan and Near Eastern Studies (Published online).

Varol, T. (2016). Russia remains determined to stop Israel-Turkey pipeline deal. Oilprice. Retrieved from http://oilprice.com/Energy/Natural-Gas/Russia-Remains-Determined-To-Stop-Israel-Turkey-Pipeline-Deal.html

Vogler, S., \& Thompson, E. V. (2015). Gas discoveries in the Eastern Mediterranean: Implications for regional maritime security. The German Marshall Fund of the United States Policy Brief 6. Retrieved from file://C:/Users/Andreas/Documents/Downloads/VoglerThompson_ImplicationsMaritimeSecurity_Mar15.pdf

Yanik, L. K. (2007). Allies or partners? An appraisal of Turkey's ties to Russia, 1991-2007. East European Quarterly, 41(3), 349-367. 